\title{
Break Time \\ Bully-Victim: Exploring What Makes an Individual Commit Bullying and How It Affects Him
}

\section{Yonas Jiwandana Putra}

English Department, Faculty of Languages and Literature, Petra Christian University, Siwalankerto 121-131, Surabaya 60236, INDONESIA

M11414038@john.petra.ac.id

\begin{abstract}
When we talk about bullying, the focus is usually about the victim and exploring how will the victim survive from that and how he overcomes that problem. However, the creative work that I make is different from the usual story. In my creative work, the point of view of story will be from a teenager who commits the bullying. In my story, it will talk about why my main character commits the bullying until he killed his classmate. He does not realize that he is manipulated by his friend and also his upper classmate called Max. The story will reveal why Ronald can become a bully in senior high. The main theme that is used in this work is how guilt changes a person's personality and way of thinking. His desire to get acknowledgement when he enters senior high and does not want to repeat the same experience in junior high makes him become a bully in senior high. The story is presented through the genre of psychology and focuses on bullying and story behind it.
\end{abstract}

Keywords: bullying, bully-victim, frenemy, Difficult home life, crime.

\section{INTRODUCTION}

Learning about theatre by being a part of theatre productions was one of my new experiences when I enrolled English for Creative Industry Program at English Department, Petra Christian University. During my study, I joined several theatre productions and got the opportunity to be responsible for several tasks such as designing property, operating lighting, managing the stage, acting and directing. In theatre, we have to be creative in designing the setting, hand prop, costume, etc. that are believable to the audience. I found out that there are a lot of things we have to prepare to create a performance. As an actor I have to focus to be the characters in a play through their dialogue and movement to create a great performance. I have to remember all the dialogue for the character that I become. I also have to remember the position and movement of the character so I can show a great performance to the audience. As a director I have to be clear what kind of message that I wanted to show and work with the artistic team to share what my idea is. I also have to lead the cast for the play to be into the character and help them with their act. I also have to think about their blocking on stage, talk with the actor and actress what kind of character they are on stage.

After I joined a theatre production and got the opportunity to take responsibility in several positions, I decided to write a play. I want to write it because I have enough knowledge about theatre. I also got knowledge in writing a good play from the class that I took before. I also want the readers to know about my original story and I want to share something through my story. That is why I decided to write a play for my final project.

In theatre, there are a lot of genres, for examples, horror, mystery, crime, and comedy. In my creative work, the genre that I choose is teen drama. I find that teen drama is suitable for my script play because drama itself is a genre that relies on emotional and relational development of real characters (thescriptlab.com). With this genre, I want to focus on the characters' struggles, emotions, and thoughts. The focus of my work will be about the character's struggles that he has to deal in daily life. How he fights and questions himself about what he has done and he takes responsibility from it. It helps me portraying a conflict that happens in daily life in a realistic way which can make readers feel more relatable.

Through this play, I want to highlight an issue that is still happening among the teenagers which is about bullying. Bullying itself is "unwanted, aggressive behavior, among school aged children that involves a real or perceived power imbalance" (stopbullying.com, n.d). From my 
experience, I have seen that bullying is still happening in every school. Back when I was in elementary school until senior high school, the act of bullying had still happened and when I was in junior high school, this act made one of a students in that school get trauma, so he did not want to go to school because he got a lot of verbal bullying at school. His friend thought that he is weird because he got gigantism syndrome that causes the individual to grow taller than average. Another case about bullying is when I was in Senior high school, a student considered as a fat student was bullied by his friends. His friends always made jokes about his fat body and sometimes abused him in the name of being "funny". With those experiences, bullying could happen anytime around us but as we can see we are not aware yet about bullying and stil think that is not a big problem. There are a lot of cases about bullying and the number of the teenagers who commits bullying keeps raising. In 2014, there are 67 cases, in 2015, there are 93 cases, and in 2016, there are 131 (jawapos.com, 2017).

Based on the data, the victims of a bullying are mostly students. I am curious to explore why the number of the victims is still increasing. In my opinion, we always take action about bullying after it happened. Because of that, I want to prevent bullying among teenagers because the major victims of bullying are mostly students. That is the reason I want to create script about bullying. In my creative work, I want to look more deeply about this issue. I want to know why someone is interested in bullying. Why do they do that? What is the trigger that makes them do the bullying? There are a lot of stories that always talk about the victim of bullying, for example Selfie by Bradley Hayward, The Other Room by Ariadne Blayde, Thank You fo Flushing My Head in the Toilet and Other Rarely Used Expression by Jonathan Dorf. In my script play, I would like to use a different point of view from a teenager who commits the bullying or called bully-victim. Bully-victim is the bully and also the victim of bullying. According to Parentingscience.com, bully-victims by contrast are both bullies and the victims of bullying. They suffer from a distinctive set of problem. For example, they may be more anxious, depressed, lonely, high-strung, and impulsive. From that point of view, I hope the readers will be aware and could prevent bullying in his surroundings.

I would like to focus on a teenager, a high school student, who commits bullying in his school and suffers after killing his classmate. During adolescence, teenagers have a tendency to try various things that seem interesting and building a peer group or getting associated with one is part of it (Indiaparenting.com, n.d). It cannot be denied that during this teenage years, the teenagers easily mingle with their friends rather than their parents. One of the issues that teenagers mostly face is bullying. According to Bullying.co.uk, teenagers bully their classmates or friends because they feel powerless. By committing bullying, they want others to think that they are not powerless. Next is they bully others because they try to get admiration and attention from their peers. Nevertheless, I believe that every teenager has his own reason on why he commits a bullying. To deliver the idea, I create a full length play with approximately 70 minutes running time.

The purpose of this work is to make the reader know and understand about what makes a telenager do a bullying and how his actions affect him. Through this project I want to show that 1) Ronald bullies Tio because of his lack of attention from his father, his bad experience when he got bullied by his friends in Junior High School, and his being manipulated Max, in Senior High School. 2) The effects of Ronald's bullying is he feels guilty and is 'haunted' by Tio.

Through my final project, I want the readers know and understand why people bully others. What makes them do such thing that hurt other people. The reader can see deeply that this bullyvictim is also the victim and the result of unsupportive society. There are many plays that talk about bullying but it is hard to find a script play about bullying in a point of view from the one who does the bullying. In this work, I want to make the reader know and understand more about bullying. This is not just to save the victim of bullying but also prevent and stop a bullying to happen again. I want to make the reader more aware with their surrounding and do action about it. At the end, with this work, I hope we save not only the victims of bullying but also the people who does the bullying. If we talk about bullying, it is not just about the one who got bullied, but also the one who is bullies is also the victim as the result of their negative surrounding and lack of support from others.

In making my creative work, I choose the idea of bullying as a big theme of the story with the point of view of the teenager who commits bullying. I would like to use an idea of why teenager bully from Dr Liam Hackett FRSA, an activist and a founder of the global equality and anti-bullying website called Ditch the Label.org. The second one is frenemy, a theory from Sherri Gordon, a 
bullying prevention advocate, an author and former editor of Colombus Parent magazine. According to the Ditchthelabel.org (n.d), "1 in 3 of those who bully people daily told us that they feel like their parents/guardians do not have enough time to spend with them" (para. 11). It makes them do not get the love and attention they should have got from their parents. Not only that, since their parents do not have enough time to spend with them, they do not have a figure to teach them between good and bad. It means that, those teenagers have bad parental supervision. Lawteacher.net once said that teenagers who have bad parental supervision are more susceptible to engage in criminal behavior. Their frustration of lack parental supervision may be expressed in destructive activities, such as bullying. All they want is to get an attention and acknowledgment. Because of that, teenagers with this kind of issue will search an attention and acknowledgment from other people. It will leads the teenagers to do a bullying since they do not know right or wrong. In other words, many of these bullying have a character of attention seeking.

Frenemy or frenemies is a term to call when a bully poses as a friend (Gordon, 2018). According to verywellfamily.com, the bullies are a master manipulators, they deceive people into believing they are friends, when really the relationship is just a means to an end. Frenemies also can use peer pressure to manipulate others. here are some characteristics of frenemy according to verywellfamily.com.

1. Frenemies enjoy intimidating other people by giving certain looks and rolling their eyes.

2. Frenemies are sometimes jealous, envious, or resentful of others.

3. Frenemies focus on being popular and sometimes will hurt others that they feel threatened by.

4. Frenemies laugh and make fun of other people for the way they dress, look or act.

As a result, frenemies are a bad relationship to be with, despite of encouraging their friends, they will manipulate and become a bad example of behavior for others. In my work, I will use this theory to portray how Max, Ronald's friend becomes the frenemy to him and how Max makes Ronald become a bully and finally bully Tio until he dies.

\section{DESIGN CONCEPT}

\section{Modes of Expression}

For the subgenre that I am going to use for my creative work is symbolic realism. In my opinion, Symbolic is the way to deliver an idea in a play without literal meaning. Realism is reality as it is. It means that, symbolic realism is how to deliver an idea of a play through symbol and meaning to portray life in artistic way. Hossain (2014) A senior lecturer from IBAIS (International Business Administration and Information System) University of English department emphasized that Realism is the artistic portrayal of life or reality as it is (p. 10). I find that this genre is suitable for my work, because by using this subgenre, I could use several settings on a stage and give deeper meaning through my play using the symbolism.

A play that inspires me to make my play is written by Mastrosimone, William. Bang Bang You're Dead. Educational Theatre Association, 1999. This play is talking about Josh, the main character, as teenager who got in jail after he killed his parents and five of his classmates. The story itself tells about Josh who got bullied by his friends and has lack of parental supervision, poor parental communication in his house and his parents only give things that he wanted but they are too busy with their job. The result of bad parental support and bad society from his friends and teachers makes him to become a person who wanted to hurt all of people who do the bad thing to him. He became a rebel person and stubborn person as the result of bad support of his surroundings. As the story goes by, Josh wanted to end all of his pain and how Josh ended all of his pain is by killing five of his classmates and also his parents. Even though he has already killed them, the pain the he felt is not gone but still remains because at the end he suffers a lot after killed his parents and his classmates.

Mastrosimone's play has a lot of symbol in his play. For example, how the five students keep haunt him and call his name and ask the reason why he killed them (Scene 1, p. 1). Mastrosimone use the students as a symbol of voices in Josh's head and shows the voices into a human being and 
keep push Josh to confess what he has done to them. Another example is when josh trap in the box (p. 17) is the symbol of how is the feeling of the five students who die and buried in a grave. This story inspired me in how the writer can make this story with a fast pace but yet I as the reader knows what he is trying to show to the audience. I can clearly understand his symbolism in this story that inspired me create such a great story like him.

However, my creative work would be different from the work that I mentioned before. In my work, I will focus on the bullying issue that might happen in school and the result of bad parental supervision by the parents and lack of discipline by the teachers in school. Not only that, my other focus will be on how Ronald's struggle to confess or not to confess after he killed his own friend. I decided to use different point of view of bullying from the one who do the bully because I want to makes the reader know that the (bully-victims) is also the victim in the first place. There is also an element of betrayal from a friend in my story. Not like Mastrosimone who uses symbolism from the beginning until the end of a play. In my play I choose to use symbol just in some part in hope that the readers can easily follow my play and still get the main idea of my play.

\section{Genre Codes and Conventions}

In this section, I would like to explain further about the genre codes and conventions that I use for my creative work, which is symbolic realism. At the table below, I have listed the main characteristics of realistic fiction.

Table 2.2.1 Table of Genre Codes and Conventions of symbolic realism

\begin{tabular}{|l|l|l|}
\hline $\begin{array}{l}\text { Story } \\
\text { Elements }\end{array}$ & $\begin{array}{l}\text { Conventions } \\
\text { Realistic drama }\end{array}$ & Conventions of My Creative Work \\
\hline Characters & $\begin{array}{l}\text { Human, ordinary } \\
\text { people, he will change } \\
\text { as the result of his } \\
\text { problem, Posthumous. }\end{array}$ & $\begin{array}{l}\text { There are three major characters in my play. The main } \\
\text { character is an ordinary high school student. He is an } \\
\text { introvert at home but rebel and stubborn as the result of } \\
\text { bad parental supervision. The second character is the main } \\
\text { character's friend, or to be exact frenemy. The third } \\
\text { character is the main character's friend who was bullied } \\
\text { by the main character until he died. Since he is dead, he } \\
\text { will apear posthumously. }\end{array}$ \\
\hline Setting & $\begin{array}{l}\text { Minimalist. The time is } \\
\text { from present to past } \\
\text { and back to present }\end{array}$ & $\begin{array}{l}\text { The setting is a visit room of a prison. As the goes by, there } \\
\text { are several changes in the setting that change into a living } \\
\text { room with only a sofa and a table to represent his living } \\
\text { room. The second one is canteen with similar property like } \\
\text { in the visit room. And an empty stage to represent a court } \\
\text { and only use lighting. }\end{array}$ \\
\hline Conflict & $\begin{array}{l}\text { Dealing with everyday } \\
\text { problem of himself, } \\
\text { family, and society }\end{array}$ & $\begin{array}{l}\text { My main character will deal problems of himself which is } \\
\text { how has wants to get out from his feeling of guilty. He also } \\
\text { has to survive from bad parental supervision and from } \\
\text { temperamental father who always abused him. How he } \\
\text { gets bully from his friends because he is an introvert and } \\
\text { does not have many friends. He tries to change not be a } \\
\text { weak person by become a bully in senior high. }\end{array}$ \\
\hline
\end{tabular}




\begin{tabular}{|l|l|l|}
\hline Solution & $\begin{array}{l}\text { Believable, as the result } \\
\text { of the character's } \\
\text { action and his friend. }\end{array}$ & $\begin{array}{l}\text { The ending of my script is how the main character struggle } \\
\text { to confess his action that killed his classmate. He finds a } \\
\text { hard way to get out from all of that and after he meets Tio } \\
\text { the student that he killed as a posthumous character he } \\
\text { finally confesses. }\end{array}$ \\
\hline
\end{tabular}

\section{THE WORK}

\section{Theme}

The subject matter of my work is bullying and the theme that I want to use in my play is how the society around, changes a person's personality and way of thinking. Throughout the story the audience will be able to explore how the society has shaped the main character into becoming a bully and even worse, a criminal. His nightmare that grew from the time when he got bullied and abused by the father eventually makes him become a bully, which is an act he does to make a difference in his senior highscool life. The main character in my story does not commit crime because he wants to do so, but rather because he thinks he has no other choice. The feeling of do not want to get bully again pushes him off the limit and makes him do things he never wants to do before. His abusive behavior from the habit of bully others becomes the core of his motivation for committing the crime. Through his crime action, the audience can see deeper that bullying is not just a victim, it is bigger than that.

\section{Plot}

A high school student in his 16 years old called Ronald. The background story of the creative work Shows when Max, his "best friend" visit him in a prison. When max visit him in a prison, Tio, a character who killed by Ronald appears as a symbol from his mind. After, the flashback for several times, it makes Ronald realize that what he did is wrong. The flashback, is he meets with his father. Then, the flashback will shows us that how max manipulated him to become a bully and the one who make Ronald to bully Tio. The climax will be when Ronald meets Tio and how Ronald deny that he killed Tio. He makes Ronald realize that what he did is wrong and make Ronald suffer by make him cannot breathe and what are the causes he gets because of his action that killed Tio. At the end, He knows that the one he trust is the one who betray him.

\section{Major characters:}

1. Ronald Herdiantoro (16 years old)

A teenager who was born in a good financial way. When he was a child, his parents were busy with their work so most of the time, Ronald was taken care by his babysitter. His parents always spoiled him and they do not have enough time with Ronald to spend with. Because he lacks of supervision by the parents, he grows into an introvert child. He finds a hard way to talk to someone and makes him does not have friends. In elementary school, he still be an introvert person and find a hard way to talk to someone. It makes him become an easy bullying target until he is in Junior High School. In his house, he cannot also be an independent person because of he always spoiled by his parents especially his mother. His father, on the other hand is a temperament person and disappointed with Ronald because his father thinks that Ronald cannot do a good things that makes his father proud. The result of both bullying and lack of supervision by his parent push him until he feels stress and depress. The result of it makes him become a bully-victim when he is in senior high school. He does that because he wants people look at him as a powerful person and not weak and to cover all of his pain. 


\section{Max (17 years old)}

Ronald's friend since in Senior high. He is the only friend and bestfriend of Ronald. He is a stubborn and also an easy going person. He can easily blend with his society. He is the only person that know about Ronald's true feeling. He is the one that makes Ronald become a bully.

\section{Tio (16 years old)}

Tio is Ronald classmate since junior high. He does not have the chance to be a friend with Tio when they were in junior high. He is a diligent and smart student since in elementary school. He is introvert and has a hard way to talks with other student. His father died when he was 5 years old and live only with his mother.

\section{Conflict}

The main conflict of this story is an inner conflict of the teenager. Inner conflict in this play is when Tio appears as the symbol of his own mind and pushes Ronald to confess his crime but Ronald does not want to admit it. My main character has struggle whether he confess or not about his crime. Tio as a symbol of his mind appears and keep pushes Ronald to confess his crime. The second one is outer conflict or man vs man conflict which is Ronald vs Max. Ronald is being pushed by Max to become a bully like him and makes Ronald think is Max is a real friend or not.

\section{Synopsis}

In short, my play talks about Ronald, a Senior high school student who commits bullying in his school and suffers from killing his classmate, Tio. As the story goes, the readers will know why Ronald becomes a bully. His bullying actions become worse when he gets jealous to Tio because his friends think that Tio is better than him. His jealousy makes his action to bully become worse and leads him to end Tio's life. In the end, he struggles whether or not he should confess about his crime.

\section{CONCLUSION}

\subsection{Concluding Thoughts}

After I have finished my creative work. I find it that this is the best version of my play. I create a play with the theme, the genre and the form that I want to use. In my play, the story could explain the statement of the problem. We can see that what are the reason of someone being a bully and leads him become a criminal. From my play, we can know that there are some factors that makes someone into a bully. The reasons are because abusive family could lead someone to become an abusive person. Not only from the family, pick the wrong friend also can be the reason someone become a bully. The effect of his crime for himself is he feels guilty but he does not want to admit his crime. He is haunted by the his classmate who died because of him.

\subsection{Lessons Learned}

Through this project, I learned how difficult it is to create a play that could offer an interesting appeal to the audience. The genre and storyline of my work are not common and I do not have a lot of references. I tried to think of a way that could raise the audience's curiosity when they read my script. I finally came up with the decision to put a twist at the end of my story, which would make the story interesting for the audience.

I found that references and opinions are always helpful in making my proposal and my play. Doing a lot of reading and watching might enable a writer to create a better script. Unfortunately, this was quite hard to do since my hobby is not reading. When I was working on this project, I had consultations with my lecturer. He is the one who always helps me to create a better play for my final project.

Another important thing that I get through this work is time management. Management is the only thing I cannot do well. I always cannot fullfil my deadline and I don't why I don't have a good time management. I tried so hard to finish this final project as hard as I can so I can graduate this semester. 


\subsection{Future Plans}

I believe that I still have a lot of improvements to do as a screenwriter. I would like to explore more genres and find more sources to read or watch in order to help me find a style that really suites me. But, to make a play is not that easy and I know how hard it is. I am aware of the fact that my work is still far from perfection. Therefore, I would like to show the final result of my work to other people which allows me to get some honest opinions and suggestion. But for now, maybe I am going to take a break after I finish my final project.

\subsection{Suggestions / Recommendation}

Working on this project has allowed me to explore more about psychological of bullying. I do not know that there are a lot of reason why people bully others. Because of that too, I realize that I sometimes become a bully when I mock my friend. Throughout the process of making this project, I also found that a bullying story is often combined with action, drama and thriller yet I also found that this genre can combined with comedy or dark comedy and not always intense. I want to deliver this because it suits my main character's thoughts and emotion since I was one of the victim of bullying also. Nevertheless, I think it would be good to do something out of the box like make a play from the point of view of the who commits bullying.

\section{REFERENCES}

Acromegaly and Gigantism. (2019). Hormone. Retrieved January 17, 2018, from https://www.hormone.org/archive/acromegaly-and-gigantism

Common types of Bullying. (2019). Parents. Retrieved September 11, 2017, from http://www.parents.com/kids/problems/bullying/common-types-of-bullying/

Dewar, G. (2018). When bullies get bullied by others: Understanding bully-victim. Retrieved January 12, 2018, from https://www.parentingscience.com/bully-victims.html

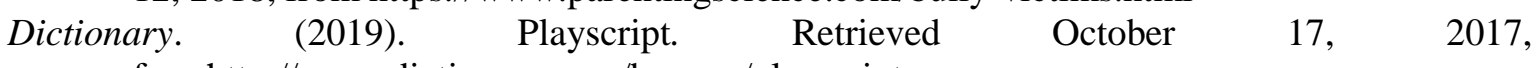
fromhttp://www.dictionary.com/browse/playscript

Gordon, S. (2018). How to Spot your Child's Frenemy. Retrieved September 26, 2018, from https://www.verywellfamily.com/is-your-childs-friend-a-bully-460640

Hossain, A. (2014). Symbolic Realism in Ibsen's Doll's House: An Overview. Retrieved January 10, 2018 ,

from http://www.academia.edu/9663001/Symbolic_Realism_in_Ibsen_s_A_Doll_s_House_An_ Overview

Jennifer, O. (2015). 7 Unexpecting Ways Acting Class Has Educational Benefits. Retrieved October 17, 2017, from https://www.noodle.com/articles/7-unexpected-ways-acting-class-haseducational- benefits

Peer Pressure and Conformity. (2019). Indiaparenting. Retrieved December 7,2018, from http://www.indiaparenting.com/peer-pressure-in teenagers/525_4961/peer-pressure-andconformity.html

Syadri, M. (2017). Full Day School Diterapkan Angka Kasus Bullying Berpotensi Naik. Retrieved September 4, 2017, from https://www.jawapos.com/read/2017/06/15/137841/full-dayschool-diterapkan-angka-kasus-bullying-berpotensi-naik

What Is Bullying. (2018, July 26). Stopbullying. Retrieved September 4, 2017, from https://www.stopbullying.gov/what-is-bullying/index.html

Why Bully. (2015). Nobullying. Retrieved on September 17, 2017, from https://nobullying.com/why-bully/

Why Children Bully. (n.d.). Bullying. Retrieved December 1, 2018, from https://www.bullying.co.uk/advice-for-parents/why-children-bully/

Why Do people Bully. (2016). Ditchthelabel. Retrieved September 24, 2017, from https://www.ditchthelabel.org/why-do-people-bully/ 